\title{
Status Kelembagaan RTRI dalam Perspektif Hukum
}

\author{
Denico Doly \\ Peneliti Muda bidang Hukum pada Pusat Pengkajian, Pengolahan Data dan Informasi \\ (P3DI), Setjen DPR RI.
}

\begin{abstract}
Public Service Broadcaster (LPP) in Indonesia is organized by Radio Republik Indonesia (RRI) and Televisi Republik Indonesia (TVRI). The main problem that these institutions have to face is the Indonesian state institution system does not recognize the status of LPP. This situation leads to other problems that hinder the development of LPP RRI and LPP TVRI. The merger between LPP RRI and LPP TVRI to become RTRI is one of the efforts in solving the problems. The status of RTRI as an independent public service broadcasting should be mentioned clearly in the regulation. Therefore, RTRI as a state institution will be independent and serves public demands on public broadcasting.
\end{abstract}

Keywords: RTRI, state institutions, public broadcasting

\begin{abstract}
Abstrak
Lembaga Penyiaran Publik (LPP) di Indonesia diselenggarakan oleh Radio Republik Indonesia (RRI) dan Televisi Republik Indonesia (TVRI). Permasalahan utama dari LPP RRI dan LPP TVRI adalah status kelembagaan yang tidak dikenal dalam sistem lembaga negara di Indonesia. Permasalahan ini kemudian menimbulkan permasalahan-permasalahan lain yang menghambat perkembangan LPP RRI dan LPP TVRI. Penggabungan LPP RRI dan LPP TVRI menjadi RTRI merupakan salah satu bentuk upaya menyelesaikan masalah dalam tubuh LPP RRI dan LPP TVRI. Status lembaga RTRI nantinya harus disebutkan secara jelas dalam peraturan perundang-undangan sebagai lembaga negara. Sehingga RTRI nantinya sebagai lembaga negara yang bersifat independent dan bertugas untuk memenuhi kebutuhan publik akan penyiaran publik.
\end{abstract}

Kata Kunci: RTRI, lembaga negara, penyiaran publik

\section{Pendahuluan}

Nama Radio Televisi Republik Indonesia (RTRI) mungkin masing terdengar asing bagi masyarakat umum. Akan tetapi, di kalangan dua lembaga Radio Republik Indonesia (RRI) dan Televisi Republik Indonesia (TVRI), sebutan RTRI sudah cukup akrab. Penyebutan ini merupakan wujud dari adanya wacana penggabungan kedua lembaga tersebut.

Wacana penggabungan RRI dan TVRI menjadi satu lembaga sebenarnya sudah lama terdengar. Hal ini diperoleh dari hasil penyusunan Rancangan Undang-Undang tentang Penyiaran (RUU Penyiaran). RTRI merupakan 
penggabungan Lembaga Penyiaran Publik (LPP) RRI dan LPP TVRI. Penggabungan tersebut dilakukan untuk melakukan efesiensi dan sekaligus memaksimalkan fungsi dari LPP untuk memenuhi kebutuhan publik akan penyiaran publik. Selama ini fungsi dari LPP RRI dan LPP TVRI belum secara maksimal dilaksanakan, hal ini dikarenakan LPP RRI dan LPP TVRI mengalami kendala dalam pengelolaan kelembagaannya. Akibatnya, berbagai fungsi dari LPP sendiri menjadi melemah. Hambatan dalam pengelolaan kelembagaan ini juga diakibatkan dari ketidakjelasan regulasi yang mengatur mengenai LPP RRI dan LPP TVRI.

LPP RRI dan LPP TVRI saat ini diatur dalam Pasal 14 ayat (2) UndangUndang Nomor 32 Tahun 2002 tentang Penyiaran (UU Penyiaran) yang menentukan bahwa LPP terdiri atas RRI dan TVRI yang stasiun pusat penyiarannya berada di ibukota Negara Republik Indonesia. Bentuk kelembagaan LPP diatur dalam Pasal 14 ayat (1) UU Penyiaran yang mengatakan bahwa LPP merupakan lembaga penyiaran yang berbentuk badan hukum yang didirikan oleh negara, yang bersifat independen, netral, tidak komersial, dan berfungsi memberikan layanan untuk kepentingan masyarakat di Indonesia. Amanat dalam pasal 14 ayat (1) ini ditujukan kepada Pemerintah Indonesia.

Pada tanggal 18 Maret 2005, Pemerintah mengeluarkan tiga peraturan pemerintah yang mengatur mengenai LPP, LPP TVRI, dan LPP RRI. Ketiga peraturan ini yakni Peraturan Pemerintah (PP) Nomor 11 Tahun 2005 tentang Penyelenggara Penyiaran Lembaga Penyiaran Publik, PP Nomor 12 Tahun 2005 tentang Lembaga Penyiaran Publik Radio Republik Indonesia, dan PP Nomor 13 Tahun 2005 tentang Lembaga Penyiaran Publik Televisi Republik Indonesia. Ketiga peraturan pemerintah ini merupakan bagian dari amanat UU Penyiaran untuk mengatur mengenai LPP. Pasal 1 angka 2 PP 11 Tahun 2005 mengatur bahwa lembaga penyiaran publik adalah lembaga penyiaran yang berbentuk badan hukum yang didirikan oleh negara, bersifat independen, netral, tidak komersial, dan berfungsi memberikan layanan untuk kepentingan masyarakat. Hal ini sejalan dengan apa yang diatur dalam Pasal 14 ayat (1) UU Penyiaran.

Meski sudah termaktub dalam PP, namun hingga saat ini LPP RRI maupun LPP TVRI masih menghadapi berbagai kendala. Salah satunya berkaitan dengan masalah pembiayaan. Sejak TVRI dan RRI dibentuk, permasalahan utamanya yaitu anggaran yang diterima tidak mencukupi untuk menunjang kegiatan-kegiatan yang dilakukan oleh kedua lembaga ini (Morissan, 2009: 99). Hal inilah yang kemudian menyebabkan TVRI dan RRI kehilangan penonton ataupun pendengar. Permasalahan yang sudah cukup lama terjadi di TVRI dan RRI ini membuat 
berbagai program acara TVRI dan RRI menjadi semakin surut pemirsanya. Akar masalah anggaran ini adalah tidak atau belum dikenalnya LPP dalam kelembagaan negara yang ada di Indonesia. Belum dikenalnya LPP menimbulkan hambatan bagi lembaga ini untuk mendapatkan anggaran yang ada dalam Anggaran Pendapatan Belanja Negara (APBN). ${ }^{1}$

Pasal 6 ayat (2) huruf b UU Nomor 17 Tahun 2003 tentang Keuangan Negara menyebutkan bahwa kekuasaan pengelolaan keuangan negara dikuasakan kepada menteri/pimpinan lembaga selaku Pengguna Anggaran/Pengguna Barang kementerian negara/lembaga yang dipimpinnya. Sedangkan dalam Penjelasan Pasal 6 ayat (2) huruf b dijelaskan bahwa yang dimaksud dengan lembaga adalah lembaga negara dan lembaga pemerintah nonkementerian negara.

Lembaga negara yang dikenal di Indonesia cukup beragam. Lembaga tinggi negara yang dikenal dan disebutkan dalam UUD 1945 antara lain MPR, DPR, DPD, Presiden dan Wakil Presiden, Mahkamah Agung, Mahkamah Konstitusi, dan BPK. Sedangkan lembaga negara dan komisi negara yang bersifat independent antara lain: Komisi Yudisial, Bank Indonesia, Tentara Nasional Indonesia, POLRI, KPU, Kejaksaan Agung, KPK dan Komnas HAM. Lembaga-lembaga negara

\footnotetext{
1 "Ketua Komisi I: RRI dan TVRI diatur dalam aturan Khusus", http://infosketsa.com (url?), diakses tanggal 19 November 2012.
}

ini merupakan lembaga-lembaga negara yang dikenal di Indonesia.

LPP RRI dan LPP TVRI selama ini bersatus sebagai lembaga penyiaran publik. Status lembaga penyiaran publik ini belum dikenal sebagai lembaga yang dapat memperoleh APBN berdasarkan ketentuan yang terdapat dalam UU Keuangan Negara. Hal ini dikarenakan lembaga penyiaran publik masih bersifat “abu-abu”, belum jelas ke mana arahnya. Pasal 15 ayat (1) huruf b UU Penyiaran mengatakan bahwa sumber pembiayaan LPP berasal dari APBN dan APBD. Akan tetapi pada kenyataannya anggaran yang diberikan oleh negara untuk LPP berasal dari APBN pada mata anggaran 69 atau Belanja Lain-Lain. ${ }^{2}$ Apabila dilihat dari UU Penyiaran, maka dapat dilihat, seharusnya LPP diberikan mata anggaran tersendiri dalam APBN. Tidak jelasnya status kelembagaan LPP menyebabkan lembaga ini tidak mendapatkan anggaran dana seperti yang seharusnya.

Permasalahan lain yang muncul yaitu mengenai sumber daya manusia (SDM) di LPP RRI dan LPP TVRI. Perekrutan SDM baru sebagai pengganti SDM lama sulit dilakukan. Hal ini dikarenakan LPP tidak jelas keberadaannya dan juga tidak jelas keikutsertaannya dalam suatu kementerian. Hal inilah yang menyebabkan LPP belum dapat menerima SDM baru maupun regenerasi pelengkapan dan peralatan penyiaran.

${ }^{2}$ Ibid. 
Permasalahan-permasalahan di atas menjadi hambatan dalam memberikan dukungan bagi bangsa dan negara melalui program siaran yang disiarkan oleh LPP. Pentingnya LPP bagi bangsa dan negara Indonesia harus didukung oleh kebijakan Pemerintah dan juga kebijakan melalui peraturan perundang-undangan. Kebijakankebijakan ini dapat memberikan dorongan bagi LPP untuk tumbuh dan berkembang, sehingga bisa menjadi salah satu lembaga penyiaran yang dapat diandalkan oleh masyarakat.

DPR RI bersama dengan Pemerintah telah menyusun program legislasi nasional tahun 2009-2014. Adapun salah satu program tersebut yaitu perubahan UU Penyiaran. Perubahan UU Penyiaran menjadi salah satu prioritas tahun 2011 dan 2012 untuk dibahas bersama oleh DPR RI dengan Pemerintah. Salah satu hal yang menjadi konsentrasi perubahan UU Penyiaran yaitu mengenai status kelembagaan LPP itu sendiri. Status yang jelas akan memberikan dampak yang signifikan terhadap LPP dalam mengembangkan program-program siaran yang telah ada dan yang akan ada. Kejelasan status kelembagaan LPP juga dapat mendorong popularitas LPP itu sendiri sehingga dapat bersaing dengan lembaga penyiaran swasta. Berdasarkan fakta tersebut, artikel ini akan membahas status lembaga RTRI dalam perspektif hukum.

\section{Lembaga Negara Bantu}

Dalam kamus Hukum Fockema Andrea yang diterjemahkan oleh Saleh Adiwinata dkk, kata "organ" diartikan sebagai alat perlengkapan (Libryanto, 2008: 44). Alat perlengkapan adalah organ atau majelis yang terdiri dari orangorang yang berdasarkan undang-undang atau anggaran dasar berwenang mengemukakan atau merealisasikan kehendak badan hukum. Dengan perantaraan alat perlengkapan itu, badan hukum ikut mengambil bagian dalam lalu lintas hukum.

Hans Kelsen mengatakan bahwa istilah “organ negara” untuk menyebut lembaga negara. Menurut Kelsen, barang siapa yang menjalankan suatu fungsi yang ditetapkan oleh tata hukum adalah suatu organ. Fungsi ini, apakah berupa perbuatan norma atau penerapannya, pada akhirnya semuanya ditujukan kepada pelaksanaan sanksi hukum. Parlemen yang menetapkan undangundang pidana, dan warga negara yang memilih parlemen adalah organ-organ negara, termasuk hakim yang menghukum si penjahat serta individu yang sesungguhnya melaksanakan hukuman tersebut (Libryanto, 2008: 4546).

Menurut Jimly Asshiddiqie (2004: 12), UUD 1945 pasca perubahan resmi menganut pemisahan kekuasaan dengan mengembangkan mekanisme checks and balances yang lebih fungsional. Dengan 
konsep pemisahan kekuasaan tersebut, format kelembagaan negara RI meliputi: MPR, DPR, dan DPD sebagai Parlemen Indonesia; Mahkamah Konstitusi dan Mahkamah Agung sebagai pemegang kekuasaan kehakiman; dan Presiden dan Wakil Presiden sebagai kepala pemerintahan eksekutif. Adapun keberadaan BPK dan Komisi Yudisial dapat dikatakan tidak berdiri sendiri. Keberadaan masing-masing beserta tugastugas dan kewenangannya haruslah dikaitkan dan terkait dengan tugas-tugas dan kewenangan lembaga yang menjadi mitra kerjanya. BPK terkait dengan DPR dan DPD, sedangkan Komisi Yudisial dengan Mahkamah Agung.

Selain lembaga-lembaga negara tersebut, bentuk keorganisasian negara modern dewasa ini juga mengalami perkembangan yang pesat. Ada dua tingkatan, pertama Tentara, organisasi Kepolisian dan Kejaksaan Agung, serta Bank Sentral. Sedangkan pada tingkatan kedua ada Komnas HAM, KPU, Komisi Ombudsman, KPPU, KPK, KKR, dan KPI. Lembaga-lembaga ini digolongkan dalam Badan-Badan Eksekutif yang bersifat independen. Komisi atau lembaga semacam ini selalu diidealkan bersifat independen dan seringkali memiliki fungsi yang campur-sari, yaitu semilegislatif dan regulatif, semi administratif, dan bahkan semi-judikatif. Dalam kaitannya dengan hal ini, terdapat istilah independent self regulatory bodies yang juga berkembang di banyak negara. Di
Amerika Serikat, lembaga seperti ini tercatat berjumlah lebih dari 30 dan pada umumnya jalur pertanggungjawabannya secara fungsional dikaitkan dengan Kongres Amerika Serikat (Asshiddiqie, 2006: 79).

Menurut HAS Natabaya, ada perkembangan mengenai klasifikasi lembaga-lembaga negara. Pertama, berdasarkan kewenangannya. Ada kewenangan lembaga negara yang diberikan oleh UUD dan ada kewenangan lembaga negara yang tidak diberikan oleh UUD melainkan oleh UU. Klasifikasi ini dilakukan mengingat adanya kewenangan Mahkamah Konstitusi untuk menyelesaikan sengketa antar lembaga negara yang kewenangannya diberikan oleh Undang-Undang Dasar. Kedua, klasifikasi lembaga negara berdasarkan pembagian lembaga negara utama (main state's organ) dan lembaga negara bantu (auxiliary state's organ). Pembagian tersebut mengacu pada pengelompokan berdasarkan ajaran trias politica (Montesquieu dan John Locke) dan ajaran catur praja Van Vollenhoven (Saly, 2007: $33)$.

Menurut Jimly Asshiddiqie (2006: 79), di negara-negara demokrasi yang telah mapan, seperti di Amerika Serikat dan Perancis, banyak pertumbuhan lembaga negara baru. Lembaga-lembaga baru tersebut biasa disebut sebagai state auxiliary organs, atau auxiliary institutions yang bersifat penunjang. Di antara lembaga-lembaga itu kadang- 
kadang ada juga yang disebut sebagai self regulatory agencies, independent supervisory bodies, atau lembagalembaga yang menjalankan fungsi campuran (mix-function) antara fungsifungsi regulatif, administratif, dan fungsi penghukuman yang biasanya dipisahkan tetapi justru dilakukan secara bersamaan oleh lembaga-lembaga baru tersebut.

Dari apa yang dikemukakan oleh HAS Natabaya dan Jimly Asshiddiqie, maka penulis berpendapat bahwa lembaga negara bantu dibentuk oleh suatu negara berdasarkan undang-undang. Lembaga tersebut dimaksudkan untuk membantu tugas dan fungsi dari suatu lembaga atau negara tersebut. Lembaga negara bantu di Indonesia yang sudah dibentuk berdasarkan undang-undang contohnya yaitu Komisi Pemberantasan Korupsi (KPK). KPK dibentuk untuk membantu Kepolisian dan Kejaksaan dalam memerangi tindak pidana korupsi.

Setelah adanya perubahan UUD Tahun 1945, di Indonesia kini banyak lembaga negara yang dibentuk baik oleh konstitusi, undang-undang, bahkan dengan keputusan presiden. Lembagalembaga ini dibentuk karena adanya kebutuhan bagi negara untuk memberikan jalan keluar dan menyelesaikan persoalan yang ada. Selain itu, kelahiran lembagalembaga negara mandiri itu merupakan bentuk ketidakpercayaan publik terhadap lembaga-lembaga yang ada dalam menyelesaikan persoalan ketatanegaraan yang dihadapi (Yazid, 2004).
Pembentukan lembaga-lembaga negara mandiri di Indonesia dilandasi oleh lima hal penting, yaitu (Tauda, 2012: 89):

1. Tidak adanya kredibilitas lembagalembaga yang telah ada sebelumnya akibat adanya asumsi mengenai korupsi yang sistemik, mengakar, dan sulit untuk diberantas.

2. Tidak independennya lembagalembaga negara yang karena alasan tertentu tunduk di bawah pengaruh suatu kekuasaan tertentu.

3. Ketidakmampuan lembaga-lembaga negara yang telah ada untuk melakukan tugas-tugas yang harus dilakukan dalam masa transisi menuju demokrasi baik karena persoalan internal maupun eksternal.

4. Adanya pengaruh global yang menunukkan adanya kecenderungan beberapa negara untuk membentuk lembaga-lembaga negara ekstra yang disebut lembaga negara mandiri (state auxiliary agency) atau lembaga pengawas (institutional watchdog) yang dianggap sebagai suatu kebutuhan dan keharusan karena lembaga-lembaga yang telah ada telah menjadi bagian dari sistem yang harus diperbaiki.

5. Adanya tekanan dari lembaga-lembaga internasional untuk membentuk lembaga-lembaga tersebut sebagai prasyarat bagi era baru menuju demokratisasi. 


\section{Komponen dalam Sistem Hukum}

Lawrence M. Friedman menjelaskan bahwa ada tiga komponen penting dari sebuah sistem hukum (legal system), yaitu structure, substance, dan culture. Untuk menggambarkan kinerjanya, ketiga komponen tersebut dapat diibaratkan sebagai sebuah mesin, maka substansi hukumnya adalah "apa yang dihasilkan atau dikerjakan oleh mesin itu". Sementara, budaya hukum adalah "apa atau siapa saja yang memutuskan untuk menghidupkan atau mematikan, menetapkan bagaimana mesin itu digunakan”. Bagi Friedman (1984: 5-14) yang terpenting adalah fungsi dari hukum itu sendiri yaitu sebagai kontrol sosial (ibarat polisi), penyelesaian sengketa (dispute settlement) skema distribusi barang dan jasa (goods distributing scheme), dan pemeliharaan sosial (social maintenance).

Salah satu komponen sistem hukum yang dikatakan oleh Friedman yaitu substansi hukum. Substansi hukum adalah aturan, norma, dan pola perilaku nyata manusia yang berada di dalam sistem. Substansi juga bisa berarti produk yang dihasilkan oleh orang yang berada di dalam sistem hukum itu, mencakup keputusan yang mereka hasilkan, aturan baru yang mereka susun. Substansi juga mencakup living law (hukum yang hidup), dan bukan hanya aturan yang ada dalam kitab undang-undang (Friedman, 1984: 8-9). Dalam tulisan ini, penulis akan memerapkan satu dari tiga komponen yang dikemukakan oleh Friedman yaitu substansi hukum.

\section{Substansi Hukum dan Lembaga Negara}

Berbagai negara di dunia baik di Eropa, Australia, Afrika, Asia, maupun Amerika, memiliki lembaga penyiaran publik. Sebut saja British Broadcasting Corporation (BBC) yang dimiliki oleh Inggris, American Broadcasting Company milik United State of Amerika, NHK milik Jepang ataupun KBS milik Korea Selatan, merupakan lembaga-lembaga penyiaran yang cukup sukses di negaranya dalam hal memenuhi kebutuhan masyarakat akan penyiaran publik. Keberadaan LPP ini menjadi sangat penting, hal ini dikarenakan berbagai hal, yaitu (Sendjaja, 2006):

a. Dalam konteks demokratisasi kehidupan berbangsa dan penguatan civil society, maka sejatinya publik berhak mendapatkan siaran yang lebih mencerdaskan, lebih mengisi kepala dengan sesuatu yang lebih bermakna.

b. Setiap warga negara berhak memperoleh siaran yang mencerdaskan tanpa adanya batasan geografis, ataupun batasan sosiopolitis.

c. LPP merupakan entitas penyiaran yang memiliki concern lebih terhadap identitas dan kultur nasional.

d. Demokratisasi media meniscayakan adanya suatu lembaga penyiaran yang 
bersifat independen, baik dari kepentingan negara maupun dari kepentingan komersil.

Berdasarkan apa yang dikemukakan di atas, maka penulis berpendapat bahwa hal-hal tersebut jarang sekali ditemui dalam kegiatan penyiaran yang dilakukan oleh lembaga penyiaran komersil atau lembaga penyiaran swasta. Hal ini dikarenakan lembaga penyiaran yang bersifat komersil lebih mementingkan rating dan pendapatan. Lembaga penyiaran komersil pada umumnya tidak mementingkan isi siaran. Unsur hiburan lebih menonjol daripada usur pendidikan. Lembaga penyiaran swasta lebih mementingkan apa yang diinginkan oleh masyarakat namun belum tentu merupakan hal yang dibutuhkan oleh masyarakat.

Isi siaran yang ditayangkan oleh lembaga penyiaran komersil ini terkadang menjadi suatu permasalahan sendiri, sebab lembaga penyiaran dapat melakukan pembentukan opini publik. Pada titik ini, LPP sebagai salah satu lembaga penyiaran yang bertujuan untuk mempersatukan bangsa dan negara, mempunyai tugas memberikan informasi, pendidikan, dan hiburan yang dibutuhkan oleh masyarakat. Kebutuhan masyarakat ini penulis artikan sebagai informasi yang benar dan berimbang, pendidikan kebudayaan dan sosial, dan hiburan yang mendidik masyarakat.

LPP RRI dan LPP TVRI merupakan lembaga penyiaran publik di
Indonesia dan dibentuk oleh UU Penyiaran. Sebelum keluarnya UU Penyiaran, RRI dan TVRI mempunyai berbagai bentuk seperti Perjan ataupun Persero. Akan tetapi setelah keluarnya UU Penyiaran, maka RRI dan TVRI dikenal sebagai Lembaga Penyiaran Publik. Pengaturan akan LPP RRI dan LPP TVRI ini kemudian diatur lebih lanjut dalam Peraturan Pemerintah Nomor 11 Tahun 2005 tentang Lembaga Penyiaran Publik (PP LPP), Peraturan Pemerintah Nomor 12 Tahun 2005 tentang Lembaga Penyiaran Publik Radio Republik Indonesia (PP LPP RRI), dan Peraturan Pemerintah Nomor 13 Tahun 2005 tentang Lembaga Penyiaran Publik Televisi Republik Indonesia (PP LPP TVRI). Ketiga peraturan pemerintah ini merupakan aturan pelaksana dari UU Penyiaran. Dalam peraturan pemerintah tersebut disebutkan secara rinci mengenai tugas, fungsi dan kewenangan LPP RRI dan LPP TVRI.

LPP RRI dan LPP TVRI merupakan salah satu lembaga yang cukup penting bagi kelangsungan hidup berbangsa dan bernegara. Pentingnya keberadaan LPP bagi masyarakat Indonesia dirasakan oleh Pemerintah Indonesia, hal ini dapat dilihat dari dukungan yang diberikan oleh Pemerintah pada saat ini yaitu dengan adanya teknik penyiaran yang dapat dilakukan oleh LPP yaitu dengan sistem teknologi digital. LPP RRI dan LPP TVRI merupakan lembaga penyiaran yang pertama kali melakukan 
penyiaran dengan sistem teknologi digital. ${ }^{3}$ Bentuk dukungan dari Pemerintah Indonesia ini menjadikan LPP RRI dan LPP TVRI menjadi lembaga penyiaran yang harus berada berada di depan lembaga penyiaran lainnya.

Kehadiran LPP RRI dan LPP TVRI merupakan wujud nyata bagi bangsa Indonesia bahwa masyarakat lebih membutuhkan informasi yang berimbang, akurat dan terpercaya, pendidikan dan juga hiburan yang sehat. Saat ini kegiatan penyiaran yang dilakukan oleh lembaga penyiaran selain lembaga penyiaran publik, menyuguhkan berbagai informasi yang dirasakan oleh masyarakat sendiri sebagai informasi yang tidak berimbang. Padahal, informasi ini dapat memberikan efek buruk bagi masyarakat dimana terjadinya pembentukan opini publik.

Selain informasi yang tidak berimbang, tayangan yang ada sekarang ini cenderung mengarah kepada tindakan kekerasan ataupun pelecehan terhadap hak-hak masyarakat. Contoh saja siaran yang ditayangkan dalam kemasan acara komedi di salah satu televisi swasta di Indonesia. Dalam acara komedi tersebut menayangkan berbagai tindakan kekerasan yang bertujuan untuk mengundang tawa penonton. Hal ini memang sebagai lelucon oleh sebagian orang, namun di sisi lain dapat menimbulkan dampak negatif bagi anakanak maupun orang dewasa.

\footnotetext{
3 "selamat datang televisi digital di Indonesia", http://teknologi.kompasiana.com, diakses tanggal 21 November 2012.
}

Isi siaran dewasa ini lebih mengarah kepada hal-hal yang minim dampak positif bagi masyarakat. Terdapat pula informasi yang tidak berimbang atau tayangan debat kusir tanpa solusi. Hal ini kemudian yang menjadikan Komisi Penyiaran Indonesia (KPI) sibuk melakukan berbagai pengawasan isi siaran yang dilakukan oleh berbagai lembaga penyiaran. Isi siaran radio ataupun televisi yang mengandung kekerasan, pelecehan, ataupun SARA menjadi sasaran utama KPI.

LPP RRI dan LPP TVRI merupakan lembaga penyiaran yang dimiliki oleh publik, dan bertugas untuk memberikan apa yang dibutuhkan oleh publik. Akan tetapi sampai dengan saat ini LPP RRI dan LPP TVRI masih memiliki berbagai permasalahan. Namun karena permasalahan regulasi dan status kelembagaan, hingga saat ini LPP belum dapat secara pasti membentuk badan hukum. Hal ini kemudian yang berimplikasi terhadap tugas, fungsi, dan kewenangan LPP RRI dan LPP TVRI.

Anggaran bagi LPP RRI dan LPP TVRI juga terbatas. Ini menjadikan isi siaran yang dilakukan oleh LPP RRI dan LPP TVRI tidak mengalami perkembangan yang signifikan. Walaupun teknologi yang digunakan oleh LPP RRI dan LPP TVRI sudah mengalami kemajuan, akan tetapi isi siaran masih dianggap belum dapat memberikan hasil yang maksimal. Akibatnya, LPP RRI dan 
LPP TVRI tidak bisa berkembang dalam pengelolaan kegiatan penyiaran.

Komisi I DPR RI saat ini sedang melakukan pembahasan Rancangan Undang-Undang tentang Penyiaran (RUU Penyiaran). RUU ini membahas mengenai penggabungan antara LPP RRI dan LPP TVRI, dan nantinya mungkin akan bernama RTRI. Pembentukan RTRI ini kemudian diamanatkan dalam RUU Penyiaran untuk diatur lebih lanjut dalam undang-undang tersendiri. 4

Tujuan dari pembentukan UU tentang RTRI adalah untuk memenuhi kebutuhan publik akan penyiaran publik. Selain itu, pengelolaan manajemen LPP akan menjadi lebih efektif. Dengan diaturnya RTRI dalam UU tersendiri, diharapkan permasalahan yang ada dalam LPP RRI dan LPP TVRI dapat terselesaikan, salah satunya adalah kejelasan status kelembagaan RTRI.

Status kelembagaan ataupun badan hukum suatu institusi merupakan kepastian hukum yang harus didapat oleh institusi tersebut. Kepastian kelembagaan atau badan hukum ini dapat berimplikasi terhadap tugas, fungsi dan kewenangan dari institusi tersebut. Status kelembagaan di Indonesia seperti Komisi Pemberantasan Korupsi (KPK), Komisi Pemilihan Umum (KPU), Lembaga Perlindungan Saksi dan Korban (LPSK), Komisi Pengawas Persaingan Usaha

\footnotetext{
${ }^{4}$ Hal ini tercantum dalam Pasal 29 ayat (3) RUU Penyiaran yang menyatakan bahwa ketentuan lebih lanjut mengenai Radio Televisi Indonesia diatur dengan undang-undang.
}

(KPPU), dan lain sebagainya dengan jelas disebutkan dalam peraturan perundangundangan. Dalam Pasal 3 UndangUndang Nomor 30 Tahun 2002 tentang KPK, misalnya, dengan jelas disebutkan KPK adalah lembaga negara yang dalam melaksanakan tugas dan wewenangnya bersifat independen dan bebas dari pengaruh kekuasaan manapun. Disebutkannya KPK sebagai lembaga negara yang dengan tegas disebutkan dalam undang-undang, membuat KPK dapat melakukan fungsi, tugas dan wewenangnya secara penuh. Ketegasan status sebagai lembaga negara mandiri ini juga membuat KPK terbebas dari interfensi pihak manapun. Seharusnya, LPP RRI dan LPP TVRI juga memiliki kejelasan status dan kebebasan seperti ini. Pembentukan lembaga negara pada LPP RRI dan LPP TVRI melalui undang-undangtersendiri merupakan salah satu jalan keluar bagi kedua lembaga ini dalam menyelesaikan permasalahanpermasalahannya. Pemberian anggaran, struktur organisasi dan juga kepegawaian dapat terselesaikan dengan adanya status kelembagaan yang jelas. Pemberian anggaran dapat dilakukan dikarenakan LPP RRI dan LPP TVRI sebagai lembaga negara diberi kepercayaan penuh untuk mengelola anggarannya.

Friedman menjelaskan, ada tiga komponen dalam sistem hukum, salah satunya adalah substansi hukum. Substansi hukum dapat berarti bahwa suatu produk hukum yang dihasilkan oleh 
orang yang berada di dalam sistem hukum itu, mencakup keputusan yang mereka hasilkan, aturan baru yang mereka susun. Pengaturan mengenai keberadaan LPP merupakan salah satu produk hukum yang harus diciptakan oleh pemerintah bersama dengan DPR RI.

Penguatan kelembagaan LPP RRI dan LPP TVRI sebagai lembaga negara, harus diperjelas dan ditegaskan dalam peraturan perundang-undangan yang dalam hal ini yaitu UU Penyiaran sebagai induk dari pembentukan Lembaga Penyiaran yang ada di Indonesia. Perubahan UU Penyiaran merupakan salah satu momentum dalam memberikan penguatan kepada LPP RRI dan LPP TVRI sebagai lembaga negara. Pembentukan lembaga negara, struktur organisasi dan sistem pembiayaan yang jelas merupakan substansi yang harus diatur dalam peraturan mengenai LPP RRI dan LPP TVRI. Undang-undang yang mengatur mengenai RTRI kelak seharusnya berisi tentang bentuk kelembagaan, susunan organisasi, dan juga kegiatan penyiaran yang dilakukan oleh RTRI.

Untuk melakukan kegiatan penyiaran publik, maka RTRI nantinya harus berorientasi kepada kepentingan publik dalam menyiarkan isi siarannya. Isi siaran yang dilakukan oleh RTRI harus memenuhi berbagai kriteria seperti isi siaran yang memiliki unsur pendidikan, kebudayaan, informasi yang berimbang dan juga hiburan yang sehat. Isi siaran yang berorientasi kepada kepentingan masyarakat harus dapat mengimbangi isi siaran yang dilakukan oleh lembaga penyiaran swasta yang sekarang ini dinilai isi siarannya kurang sehat dan mendidik masyarakat.

Lembaga penyiaran publik mempunyai karakteristik yang berbeda dengan karakteristik yang dimiliki oleh lembaga penyiaran swasta/komersil. Adapun kekhasan karakteristik lembaga penyiaran publik di antaranya (Rachmiatie, 2006: 284):

a. Punya visi untuk memperbaiki kualitas kehidupan publik, bangsa dan hubungan antarbangsa.

b. Punya misi untuk menjadi forum diskusi, artikulasi dan pelayanan kebutuhan publik.

c. Ada pengakuan signifikan terhadap pengawasan dan evaluasi oleh publik sebagai khalayak dan partisipan yang aktif

Sementara indikator yang khas dari LPP sehingga berbeda dengan lembaga penyiaran swasta yaitu (Rachmiatie, 2006: 284):

a. Akses publik: didirikan tidak hanya berdasarkan potensi ekonomi, namun dengan pertimbangan pemerataan informasi; misalkan daerah terpencil/blank spot.

b. Dana Publik : menggunakan dana pemerintah dalam bentuk APBN dan APBD. 
c. Akuntanbilitas publik: mempertanggungjawabkan program dengan ukuran moral dan tata nilai publik (moral accountanbility); mempertanggungjawabkan keuangan (financial accountanbility).

d. Keterlibatan publik: ada kerjasama seluas-luasnya dengan berbagai kelompok di masyarakat, mengundang serta menyambut keterlibatan publik.

Peranan LPP sebagai lembaga penyiaran sesungguhnya sudah dirasakan oleh masyarakat pada saat masa penjajahan. LPP RRI merupakan salah satu lembaga penyiaran yang memberikan dukungan secara penuh terhadap kemerdekaan Indonesia. Hal ini dapat dilihat dengan pemberitaan secara langsung mengenai pidato kemerdekaan yang disampaikan oleh Presiden Soekarno.

Saat ini peranan dari LPP yaitu untuk mempersatu seluruh masyarakat di Indonesia. Siaran yang dilakukan oleh LPP harus dapat menjangkau seluruh wilayah Indonesia termasuk sampai seluruh pelosok tanah air. Kedaulatan negara Indonesia pada saat sekarang ini juga menjadi tugas dari LPP sebagai lembaga penyiaran. Wilayah perbatasan Indonesia menjadi permasalahan tersendiri, tidak terjangkaunya siaransiaran yang dilakukan oleh lembaga penyiaran swasta harus dapat diatasi oleh LPP. LPP harus dapat memberikan informasi dan pendidikan kepada masyarakat yang berada di daerah perbatasan. Hal ini untuk mencegah terjadinya perpindahan penduduk ataupun pemihakan kepada negara tetangga oleh masyarakat perbatasan.

Kejelasan status kelembagaan LPP menjadi salah satu bentuk penguatan LPP dalam melaksanakan tugas, fungsi dan wewenangnya. Pemberian status kelembagaan itu juga harus dituangkan dalam peraturan perundang-undangan. Hal ini untuk memberikan kepastian hukum kepada LPP dalam melaksanakan tugasnya. Status LPP sebagai lembaga negara merupakan penguatan terhadap LPP dalam melaksanakan visi dan misinya. Menurut pendapat penulis, LPP layak untuk diberikan status sebagai lembaga negara, hal ini dikarenakan fungsi, tugas dan wewenang dari LPP adalah untuk kepentingan bangsa dan negara yang berorientasi kepada seluruh masyarakat Indonesia.

\section{Penutup}

LPP mempunyai tugas untuk memberikan informasi, pendidikan dan hiburan yang sehat kepada masyarakat Indonesia. Meski demikian, keberadaan LPP RRI dan LPP TVRI saat ini dinilai belum dapat melaksanakan tugas dan kewenangannya dengan baik. Hal ini dikarenakan belum adanya kejelasan mengenai status badan hukum LPP RRI dan LPP TVRI. 
Untuk mempertegas dan memberikan penguatan terhadap kelembagaan dari RRI dan TVRI, maka perlu ada perubahan mendasar dari segi peraturan perundangan yang berlaku, yaitu perubahan UU Penyiaran. Selain perubahan UU Penyiaran, maka perlu juga mengubah kelembagaan LPP RRI dan LPP TVRI yaitu dengan menggabungkan RRI dengan TVRI menjadi satu lembaga yang nantinya disebut dengan RTRI. Perubahan ini diharapkan dapat memberikan penyelesaian terhadap permasalahan-permasalahan yang dihadapi oleh RRI dan TVRI.

Secara hukum, salah satu substansi penting yang perlu ditegaskan yaitu mengenai status kelembagaan dari penyelenggara penyiaran publik atau lembaga penyiaran publik. Adapun penegasan itu yaitu dengan menyebutkan secara pasti bahwa lembaga penyiaran publik dilakukan oleh RTRI sebagai lembaga negara yang didirikan oleh negara yang bersifat independen.

\section{Daftar Pustaka}

Asshiddiqie, Jimly. 2004. Format Kelembagaan Negara dan Pergeseran Kekuasaan Dalam UUD 1945. Yogyakarta: FH UII Press.

Asshiddiqie, Jimly. 2006. Pengantar Ilmu Hukum Tata Negara, Jakarta: Sekertariat Jenderal dan Kepaniteraan Mahkamah Konstitusi Republik Indonesia.
Friedman, Lawrence M. 1984. American Law: An Introduction. New York: W.W. Norton \& Company.

Hakim, Lukman. 2010. Kedudukan Hukum Komisi Negara di Indonesia. Malang: PPS UB, Puskasi Univ. Widyagama Malang dan Setara Press.

Judhariksawan. 2010. Hukum Penyiaran. Jakarta: Rajagrafindo Persada.

Morissan, M.A. 2009. Manajemen Media Penyiaran: Strategi Mengelola Radio dan Televisi. Jakarta: Kencana Prenada Media Group.

Libryanto, Romi. 2008. Trias Politica dalam Struktur Ketatanegaraan Indonesia. Makasar: PuKAP.

Peraturan Pemerintah Republik Indonesia Nomor 11 Tahun 2005 Tentang Penyelenggaraan Penyiaran Lembaga Penyiaran Publik.

Peraturan Pemerintah Republik Indonesia Nomor 12 Tahun 2005 Tentang Lembaga Penyiaran Publik Radio Republik Indonesia.

Peraturan Pemerintah Republik Indonesia Nomor 13 Tahun 2005 Tentang Lembaga Penyiaran Publik Televisi Republik Indonesia.

Rachmiatie, Atie. 2006. "Konsistensi Penyelenggaraan RRI dan TVRI sebagai Lembaga Penyiaran Publik”. MediaTor, Vol. 7 No. 2, 2006. 
Saly, Jeane Neltje. 2007. "Hubungan Antar Lembaga Negara dalam Perspektif Pasca Amandemen UUD 1945”. Jurnal Legislasi Indonesia, Volume 4 Nomor 3 September 2007. Jakarta : Direktorat Jenderal Peraturan Perundang-undangan Departemen Hukum dan HAM RI.

Sendjaja, Sasa Djuarsa. 2006. "Badan Hukum TVRI dan RRI Sebagai Lembaga Penyiaran Publik”. Jurnal Bisnis dan Birokrasi No. 2/vol.XIV/Mei 2006.

Tauda, Gunawan A. 2012. Komisi Negara Independen: Eksistensi Independent Agencies sebagai Cabang Kekuasaan Baru dalam Sistem Ketatanegaraan. Yogyakarta: Rajawali.

Undang-Undang Nomor 32 Tahun 2002 tentang Penyiaran, Lembaran Negara Republik Indonesia Tahun 2002 Nomor 139, Tambahan Lembaran Negara Republik Indonesia Tahun 2002 Nomor 4252.

Undang-Undang Nomor 30 Tahun 2002 tentang Komisi Pemberantasan Korupsi, Lembaran Negara Republik Indonesia Tahun 2002 Nomor 137, Tambahan Lembaran Negara Republik Indonesia Tahun 2002 Nomor 4250.

Wiryawan, Hari . 2007. Dasar-Dasar Hukum Media. Yogyakarta: Pustaka Pelajar.
Yazid, T.M. Luthfi. Komisi-komisi Nasional dalam Konteks Cita-cita Negara Hukum. Makalah, disampaikan dalam Diskusi Terbatas dengan tema Eksistensi Sistem Kelembagaan Negara Pascaamandemen UUD 1945, diselenggarakan oleh Konsorsium Reformasi Hukum Nasional, di Hotel Aryaduta, Jakarta, 9 September 2004.

"Ketua Komisi I: RRI dan TVRI diatur dalam aturan Khusus”. http://infosketsa.com. Diakses tanggal 19 November 2012.

. "Kualitas Acara Televisi Kita Masih Buruk". http://duniatv.blogspot.com. Diakses tanggal 21 November 2012.

. "Menguatkan RRI sebagai Radio Publik”.

http://sugengwin.staff.umm.ac.id - Diakses tanggal 19 November 2012.

"Pemusatan Kepemilikan Lembaga Penyiaran dapat Giring Opini Publik”. http://www.medanbisnisdaily.co m/news $/ \mathrm{read} / 2012 / 01 / 10 / 75590$. Diakses tanggal 30 Oktober 2012. . "Penyatuan TVRI dan RRI diwacanakan".

http://www.kpi.go.id. Diakses tanggal 19 November 2012. 
. "Selamat Datang Televisi Digital

di Indonesia”.

http://teknologi.kompasiana.com.

Diakses tanggal 21 November 2012 
Jurnal komunikasi, Volume 7, Nomor 2, April 2013 